\title{
Design and Analysis of Go-Kart Chassis
}

\author{
Syed Azam Pasha Quadri ${ }^{1}$, Mohd Yousuf Ahmed ${ }^{2}$, Mohammed Salman ${ }^{3}$ Mohd Yousufuddin \\ Professor and Head of the department, Mechanical Department, Lords Institute of Engg \& Tech, Hyderabad, India ${ }^{1}$ \\ Assistant Professor, Mechanical Department, Lords Institute of Engg \& Tech, Hyderabad, India ${ }^{2}$ \\ Student, Mechanical Department, Lords Institute of Engg \& Tech, Hyderabad, India ${ }^{3,4}$
}

\begin{abstract}
A Go-kart is a small four wheeled vehicle. Go-kart, by definition, has no suspension and no differential. They are usually raced on scaled down tracks, but are sometimes driven as entertainment or as a hobby by nonprofessionals. 'Carting is commonly perceived as the stepping stone to the higher and more expensive ranks of motor sports. Kart racing is generally accepted as the most economic form of motor sport available. As a free-time activity, it can be performed by almost anybody and permitting licensed racing for anyone from the age of 8 onwards. Kart racing is usually used as a low-cost and relatively safe way to introduce drivers to motor racing. Many people associate it with young drivels, but adults are also very active in karting. Karting is considered as the first step in any serious racer's career. It can prepare the driver for highs-speed wheel-to-wheel racing by helping develop guide reflexes, Precision car control and decision-making skills. In addition, it brings an awareness of the various parameters that can be altered to try to improve the competitiveness of the kart that also exist in other forms of motor racing.
\end{abstract}

Keywords: Go-kart, Racing, Design, Frame, Analysis.

\section{INTRODUCTION}

In the case of vehicles, the term CHASSIS can be described as the frame which supports all the components of the vehicle. The wheels of the vehicle are mounted on the chassis with the help of king pin and sprockets and the other parts are also attached with bolts and welding process. The chassis should be rigid from all the Bending and Torsion stress. To ensure the safety of the driver the chassis should be designed to comply with basic safety rules and at the same time serve its purpose.

\section{DESIGN METHODLOGY}

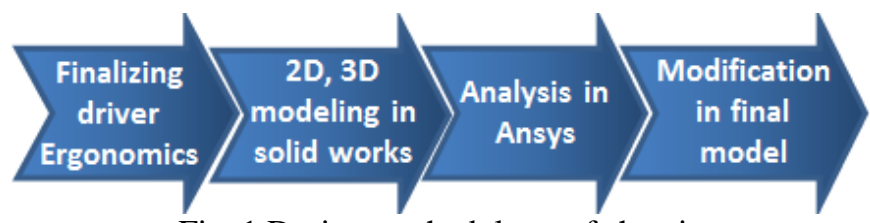

Fig. 1.Design methodology of chassis

\section{CHASSIS}

A. Goals

- To ensure safety of the driver.

- To maintain low center of gravity.

- To ensure that all the systems fit onto the chassis.

- To design a chassis with high strength and low weight.

B. Our design specifications

- Wheelbase: $1220 \mathrm{~mm}$

- Track width $70 \%$. Of the wheelbase i.e (863mm)

- Overall length: The overall length of the vehicle is $1651 \mathrm{~mm}$ excluding the front and rear bumpers

- Roll Bar is used in the structure and its top is extended over the drivers helmet

TABLE I SPECIFICATIONS OF CHASSIS

\begin{tabular}{|c|c|}
\hline Chassis weight & $25 \mathrm{Kgs}$ \\
\hline Width & $838 \mathrm{~mm}$ \\
\hline Wheel base & $1220 \mathrm{~mm}$ \\
\hline
\end{tabular}


International Advanced Research Journal in Science, Engineering and Technology ISO 3297:2007 Certified

Vol. 4, Issue 5, May 2017

\begin{tabular}{|c|c|}
\hline Track width (front) & $863 \mathrm{~mm}$ \\
\hline Weight distribution & $40: 60$ \\
\hline Total weight & $140 \mathrm{Kgs}$ \\
\hline
\end{tabular}

C. Chassis views

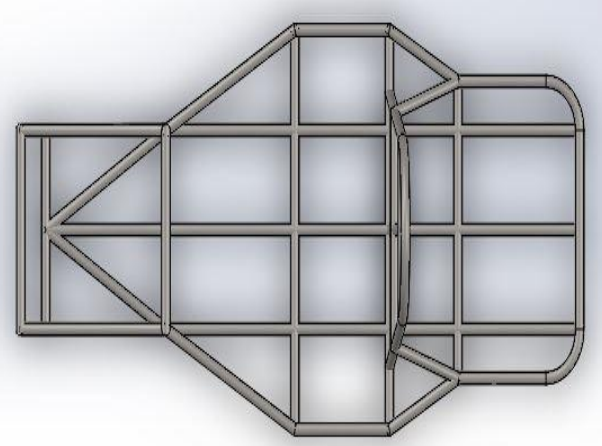

Fig. 2. Top view of chassis

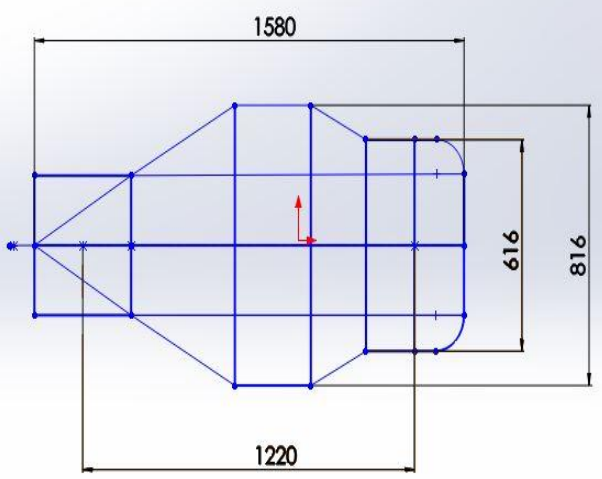

Fig. 3. Top view with dimensions

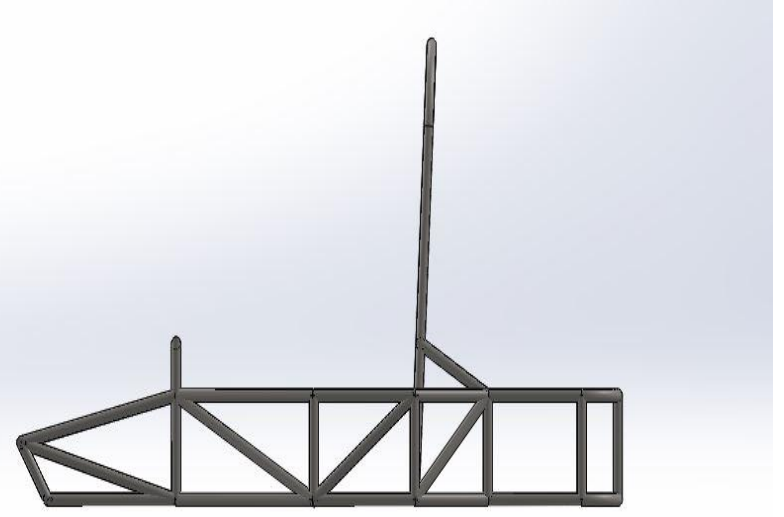

Fig. 4. Side view 
ISO 3297:2007 Certified

Vol. 4, Issue 5, May 2017

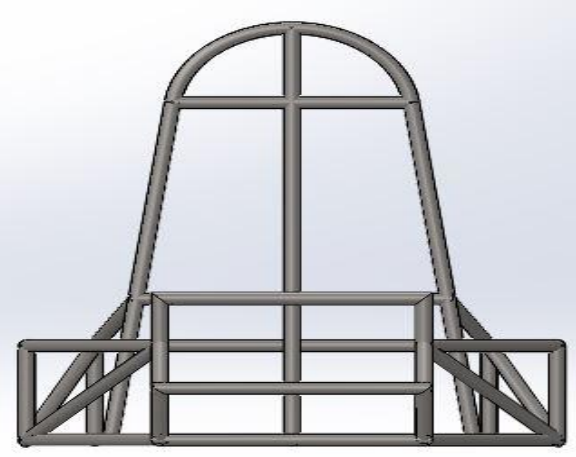

Fig. 5. Front view

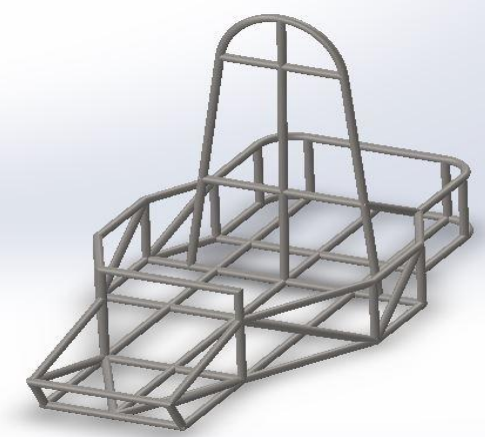

Fig. 6. Isometric view of chassis

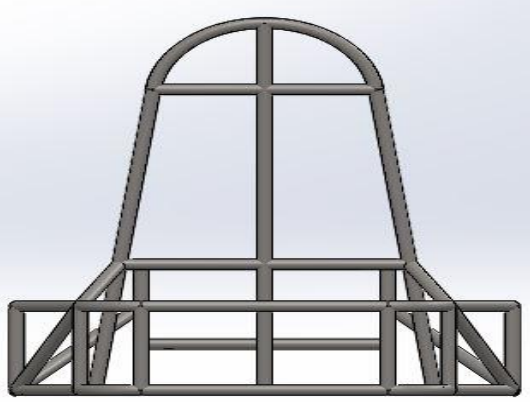

Fig. 7. Rear view

\section{MATERIAL SELECTION}

Cost, availability, weight, strength \& weld ability are the four key factors which determine the material selection. Tubing is available in standard fractional sizes to the 1/8th of an inch: $1,1.12,1.25$ and 1.5. The wall thickness is limited to the common Birmingham Tubing Gauges. In this case these are: 1.5, 1.8, 2, 2.5 and 3 mm. The most commonly available materials are:

TABLE II COMPARISON OF MATERIAL PROPERTIES

\begin{tabular}{|c|c|c|}
\hline Materials & Yield strength (MPa) & Percentage elongation at break \\
\hline AISI 1026 & $260-440$ & $17-27 \%$ \\
\hline AISI 4130 & $435-979$ & $18-26 \%$ \\
\hline AISI 1020 & $230-370$ & $18-28 \%$ \\
\hline AISI 1018 & $270-400$ & $18-29 \%$ \\
\hline
\end{tabular}


Vol. 4, Issue 5, May 2017

It is observed that material which has high machinability and inexpensive is AISI 1018 hence was a good choice but strength to weight ratio is greater for 4130. AISI 1020 was rejected because of its high cost. AISI 4130 was rejected because of its high carbon content and lack of Machinability, 4130 have the superior harden ability that other iron alloys like 4130 and 4140 possess. But 4130 is popular steel in race car industry but is not easily available in India.

Therefore, the material that the team chose to use is AISI 1018. The benefit of using the AISI 1018 is that it can be easily wielded than the 4130 chromyl. The AISI 1018 has the same Modulus of Elasticity (E) and density as the 4130, so using it does not affect the weight or stiffness in member with same geometry.

AISI 1018 has excellent weld ability and produces a uniform and harder case and it is considered as best steel for carburizing parts. The 1018 carbon steel offers a good balance of toughness, strength and ductility. Considering the above factors we choose AISI 1018 for our chassis material.

TABLE III CHEMICAL COMPOSITION OF AISI 1018

\begin{tabular}{|c|c|}
\hline Chemical composition of AISI 1018 ELEMENT & CONTENT \\
\hline Carbon (C) & $0.14-0.20 \%$ \\
\hline Sulphur (S) & $<=0.050 \%$ \\
\hline Iron (Fe) & $98.81-99.26 \%$ \\
\hline Manganese (Mn) & $0.60-0.90 \%$ \\
\hline Phosphorous (P) & $<=0.040 \%$ \\
\hline
\end{tabular}

TABLE IV SPECIFICATION OF MATERIAL SELECTED

\begin{tabular}{|c|c|}
\hline Primary members Wall thickness & $2 \mathrm{~mm}$ \\
\hline Secondary members wall thickness & $1.2 \mathrm{~mm}$ \\
\hline Primary members diameter & $1 \mathrm{inch}$ \\
\hline Secondary member diameter & $1 \mathrm{inch}$ \\
\hline
\end{tabular}

TABLE V PHYSICAL PROPERTIES OF AISI 1018

\begin{tabular}{|c|c|}
\hline PROPERTIES & VALUE(Metric) \\
\hline Density & $7.87 \mathrm{~g} / \mathrm{cc}$ \\
\hline Yield tensile strength & $370 \mathrm{MPa}$ \\
\hline Ultimate strength & $440 \mathrm{MPa}$ \\
\hline Elongation at break(in 50 mm) & $15 \%$ \\
\hline Poisons ratio & 0.29 \\
\hline Modulus of elasticity & $200 \mathrm{GPa}$ \\
\hline
\end{tabular}

A. Floor pan material

Aluminium checker sheet is selected for floor pan

\section{VIEWS OF THE KART}

A. Cad Model

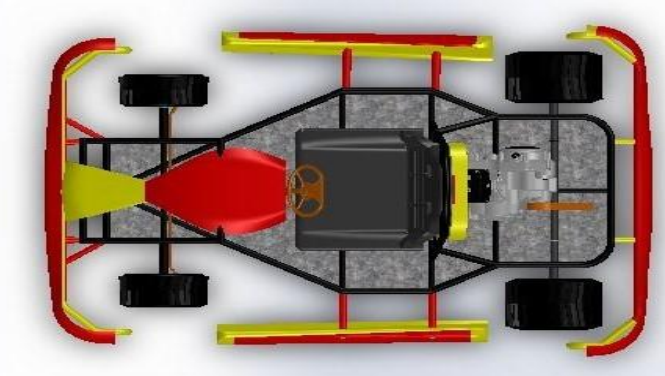

Fig. 8. Top view 
International Advanced Research Journal in Science, Engineering and Technology ISO 3297:2007 Certified

Vol. 4, Issue 5, May 2017

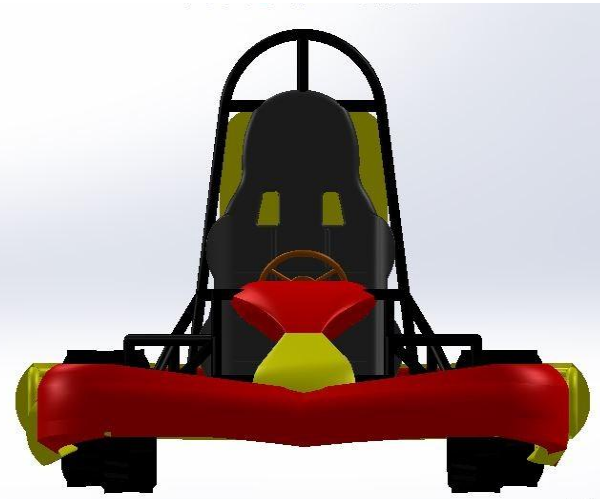

Fig. 9. Front view

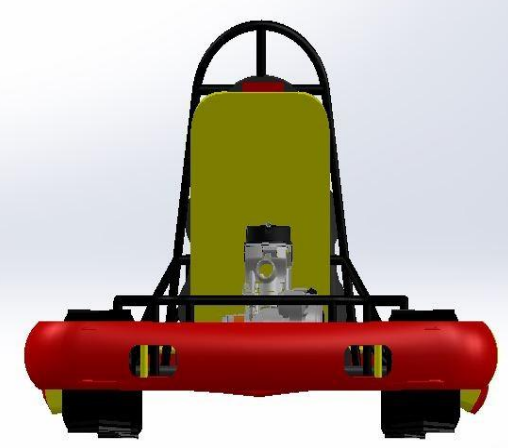

Fig. 10. Rear view

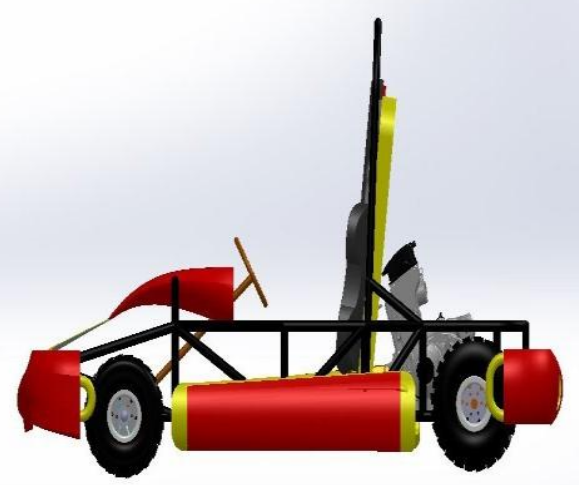

Fig.11. Side view

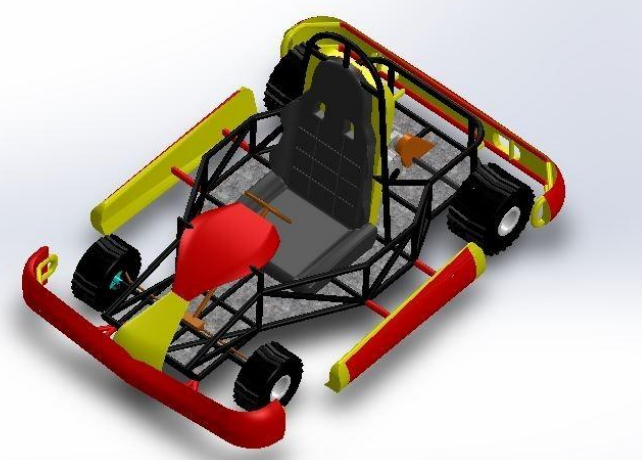

Fig. 12.Isometric view 


\section{International Advanced Research Journal in Science, Engineering and Technology}

ISO 3297:2007 Certified

Vol. 4, Issue 5, May 2017

B. Bumpers and Body Works

External appearance of the vehicle depends upon bodyworks. It is an important part of the vehicle design. It also dominates sale and marketing of the vehicle.

We have selected fiber /fabricated on the basis of market survey because of its

- light weight

- good electrical insulator

Bumpers are made of steel material with upper pipe and lower pipe with diameter as $16 \mathrm{~mm}$ and $20 \mathrm{~mm}$ resp. and thickness of $2 \mathrm{~mm}$ and will be covering with fiber/fabricated wax for the external appearance.

The above dimensions are for front, rear and side bumpers.

1. Firewall: Fire Wall Has Been Incorporated In the Design of the Go-kart for the Safety of the Driver aluminium is selected as the firewall material and it coated with sodium silicate to prevent the heating.

\section{ANALYSIS}

Structure, after designing must be validated to know its reliability. Conventionally in FEA, the frame is subdivided into elements. Nodes are placed where tubes of frame join. The assumption made in using beam elements is that the welded tubes have stiffness in bending and torsion, thus a higher factor of safety is desirable

\section{A. Frontal Impact}

Frontal impact has been done by considering the kart going at its maximum possible top speed and undergoing a head collision with a rigid body. Load of $8000 \mathrm{~N}$ was applied during the analysis.

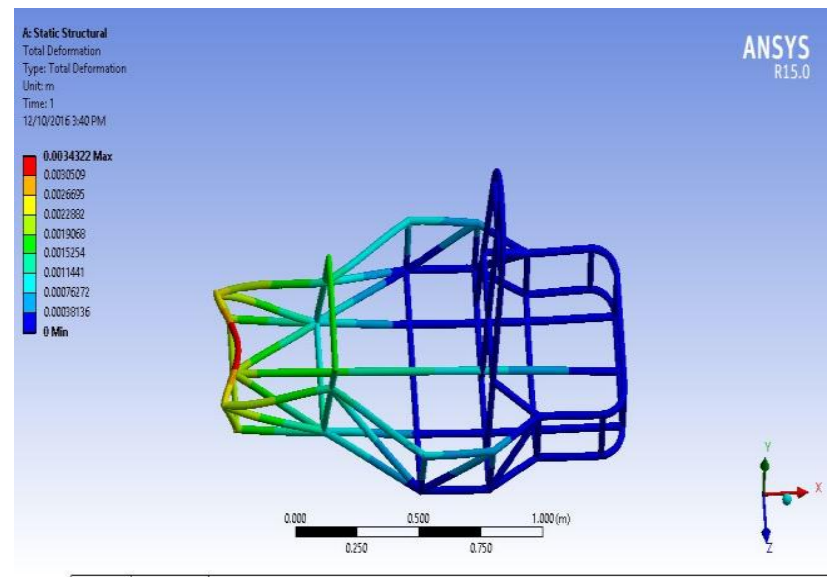

Fig. 13. Deformation during front impact

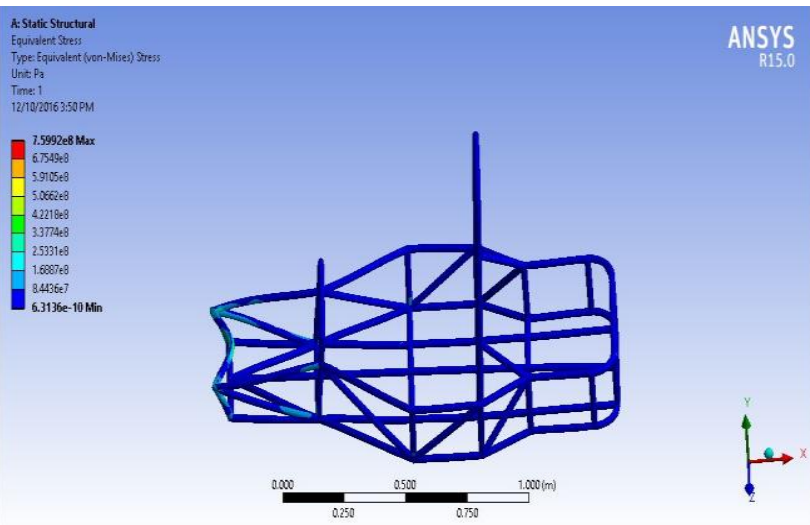

Fig. 14. Stresses during front impact

TABLE VI FRONT ANALYSIS RESULT

\begin{tabular}{|c|c|}
\hline Load applied & $8000 \mathrm{~N}$ \\
\hline Maximum deformation & $0.0034322 \mathrm{~m}$ \\
\hline
\end{tabular}


International Advanced Research Journal in Science, Engineering and Technology

ISO 3297:2007 Certified

Vol. 4, Issue 5, May 2017

\begin{tabular}{|c|c|}
\hline Maximum stress & $759.92 \mathrm{MPa}$ \\
\hline FOS & 1.5 \\
\hline
\end{tabular}

B. Rear Impact

The rear impact analysis has been done by considering the kart getting hit by another vehicle at its top speed the force calculations are same as that of front impact. Load of $8000 \mathrm{~N}$ was applied during analysis.

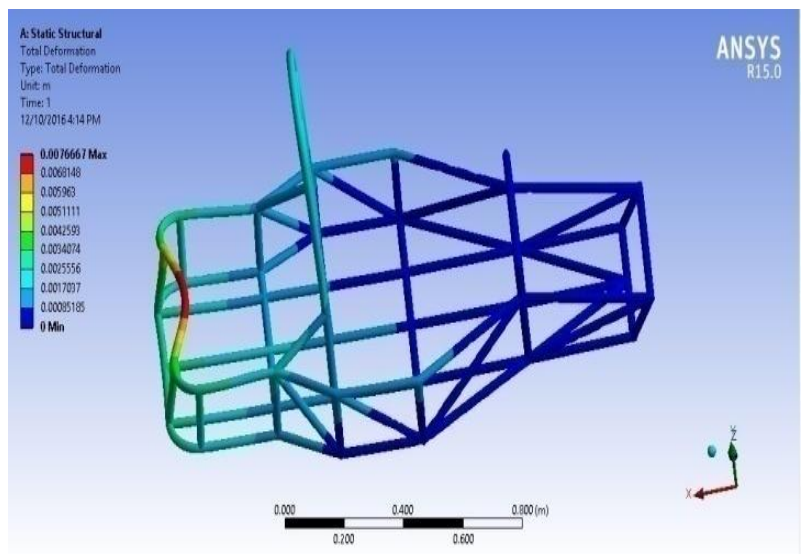

Fig. 15. Deformation during rear impact

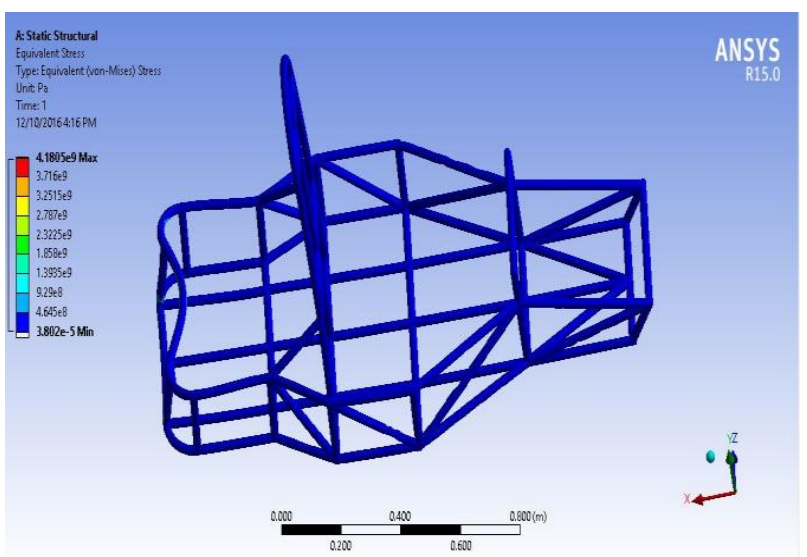

Fig.16 Stress during rear impact

TABLE VII REAR ANALYSIS RESULT

\begin{tabular}{|c|c|}
\hline Load applied & $8000 \mathrm{~N}$ \\
\hline Maximum deformation & $0.0076667 \mathrm{~m}$ \\
\hline Maximum stress & $4180.5 \mathrm{MPa}$ \\
\hline FOS & 1.91 \\
\hline
\end{tabular}

C. Side impact

Load of $8000 \mathrm{~N}$ was applied during the analysis

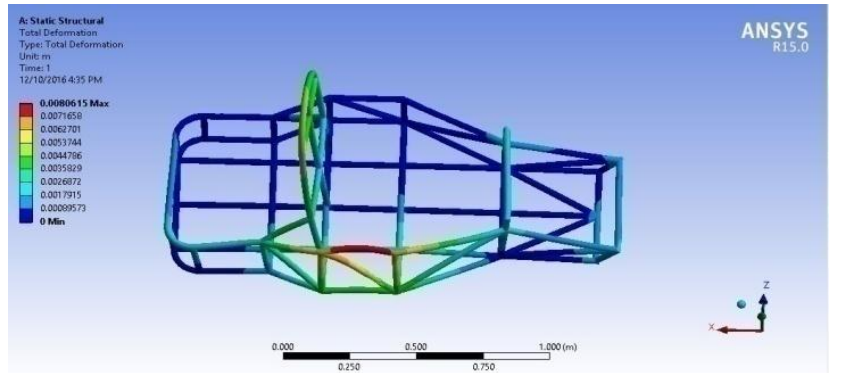

Fig. 17. Deformation on Right Side during Torsion 


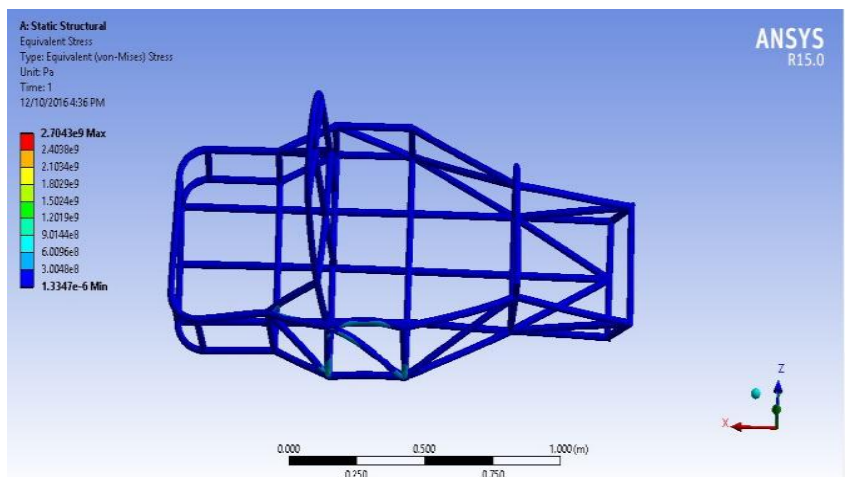

Fig. 18. Stress on Right Side

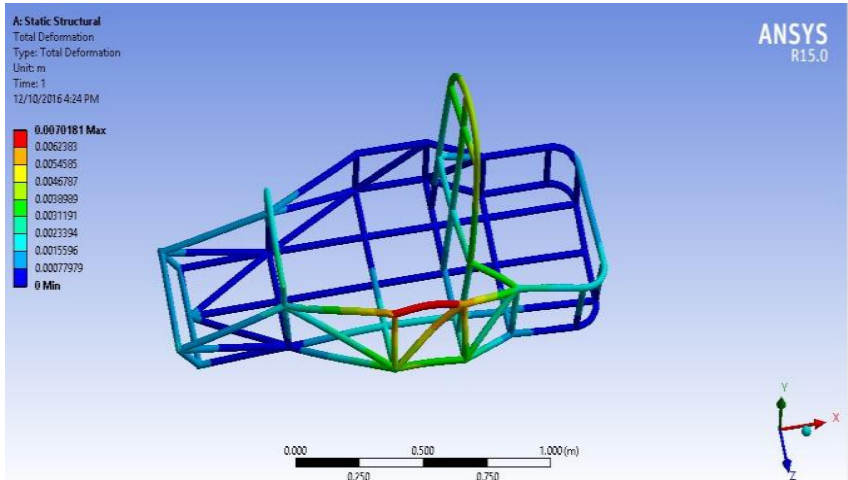

Fig. 19. Deformation on Left Side

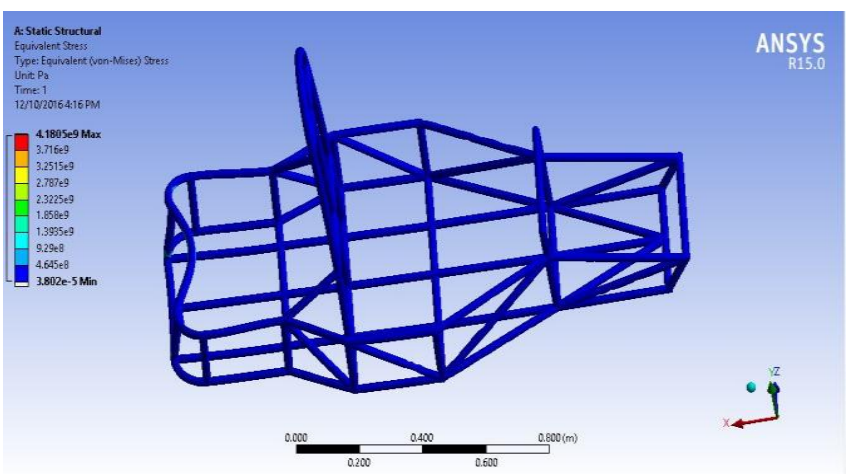

Fig. 20. Stress on Left Side

TABLE VIII SIDE ANALYSIS RESULT

\begin{tabular}{|c|c|}
\hline Deformation right side & $0.0080615 \mathrm{~m}$ \\
\hline Deformation left side & $0.0070187 \mathrm{~m}$ \\
\hline Stress of right side & $2704.3 \mathrm{MPa}$ \\
\hline Stress on left side & $2494.6 \mathrm{MPa}$ \\
\hline
\end{tabular}

\section{CONCLUSION}

The design and construction for GO-KART has become more challenging due to the increased participation. Our team is participating for the first time in this event so a detailed study of various automotive systems is taken as our approach. Thus this report provides a clear insight in design and analysis of our vehicle. The making of this report has helped us in learning of various software. We want to give a vote of Thank you in this regard as IGC competition has given as this opportunity to learn many things which will also help us in leading a bright future

We have designed it keeping in mind the safety of the driver as well as the kart and also which is light in weight. We have incorporated many sensors in the go-kart and also some automated systems has also been used and we call it as smart go-kart. 
We would like to conclude by saying that keeping in mind the design of conventional go-kart we have design our gokart in the firm of F1 type approach

\section{ACKNOWLEDGMENT}

We would like to thank our college, Lords Institute of Engineering \& Technology, Hyderbad for providing us with moral support and different lab facilities. Also, we would like to thank the Head of Department (Department of Mechanical Engineering) Dr. Syed Azam Pasha Quadri We would also thank Mr. Mohd Yousuf Ahmed (Assistant Professor Dept. of Mechanical Engineering) for providing us with mentorship.

\section{REFERENCES}

[1] Shaik Himam Saheb, Govardhana Reddy, Md. Hameed Design Report of a go-Kart Vehicle vol. 1, issue 9, issn no. 2455-2143, pages 95-102 published online july - august 2016 in ijeast (http://www.ijeast.com) international journal of engineering applied sciences and technology, 2016

[2] Ravindra Laxman Gaikwad, Prathmesh Vishwas waghmare, Lalit Daulatrao Deore3, Akshay Mukesh Mutake Design of Go-Kart vehicle systems vol. No.4, issue no.03, march 2016 IJATES

[3] Anjul Chauhan Lalit Naagar Sparsh chawla

[4] Design and Analysis of a Go-Kart, International Journal of Aerospace and Mechanical Engineering volume 3 - no.5, September 2016

[5] Automobile Engineering by R.K Rajput

[6] Theory of Machines, by R.S Khurmi, JK Gupta

[7] Machine Design by R.S Khurmi, JK Gupta

[8] Tune to Win by Carroll Smith

[9] Race Car Vehicle Dynamics by Milliken \& Milliken

[10] Vehicle Dynamics: Theory and Application by Reza N Jazar

[11] Introduction to Chassis Design by Keith J. Wakeham

[12] Racing and Sports Kart Chassis Design by Michael Costin and David Phipps

[13] Mechanics of Materials by Beer and Johnston

[14] www.kartpedia.com

[15] Wikipedia

\section{BIOGRAPHIES}

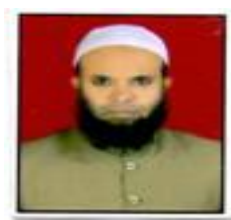

Dr. Syed Azam Pasha Quadri was born in the city of Andhra Pradesh, Hyderabad in 1975. He received the B.E from Osmania University in April 1998, M.TECH from JNTU Anantapur in August2006 and Ph.D. degree from N.I.T Warangal in February 2016, respectively. His main areas of research interest are I.C Engines, Alternative Fuel, Non convectional resources. Dr. Syed Azam Pasha Quadri is holding a position as Head of the department (HOD) in Lords Institute of Engineering and Technology.

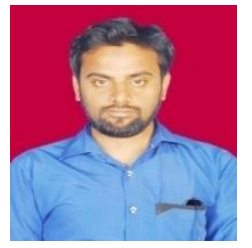

Mr. Mohd Yousuf Ahmed was born in the city of Andhra Pradesh (Now in Telangana), Karimnagar in 1990. He received the B.Tech from Mother Theressa College of Engineering \&amp; Technology, JNTU HYD, Karimnagar in May 2013 and M.E. from Muffakham Jah College of Engineering and Technology, Osmania University, Hyderabad in September 2015, respectively. Mr. Mohd Yousuf Ahmed is an Assistant Professor in Lords Institute of Engineering and Technology.

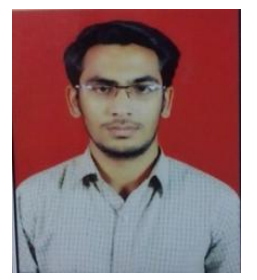

Mohamme d Salman was born in the year 1996 in Hyderabad Andhra Pradesh (now in Telangana). He is pursuing B.Tech (Mechanical) from Lords Inst of Engg and Tech, Hyderabad and is presently in the final year. His main areas of interest are automobiles and designing. 